\title{
A Plan for Addressing the Financial Crisis
}

\section{Citation}

Lucian A. Bebchuk, A Plan for Addressing the Financial Crisis, The Economists' Voice, Sept. 2008.

\section{Published Version}

http://dx.doi.org/10.2202/1553-3832.1416

\section{Permanent link}

http://nrs.harvard.edu/urn-3:HUL.InstRepos:26356100

\section{Terms of Use}

This article was downloaded from Harvard University's DASH repository, and is made available under the terms and conditions applicable to Other Posted Material, as set forth at http:// nrs.harvard.edu/urn-3:HUL.InstRepos:dash.current.terms-of-use\#LAA

\section{Share Your Story}

The Harvard community has made this article openly available.

Please share how this access benefits you. Submit a story.

Accessibility 


\title{
A Better Plan for Addressing the Financial Crisis
}

\author{
LUCIAN A. BEBCHUK
}

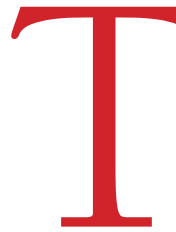

he current financial crisis is widely viewed as the most serious since the Great Depression. Last week, facing severe market reactions to the failures of AIG and Lehman Brothers, the US Treasury Department put forward a bold and massive program of spending up to $\$ 700$ billion on purchasing "troubled assets" from financial institutions.

This paper critiques this proposed emergency legislation. It also puts forward a superior alternative for advancing the two goals of the proposed legislation-restoring stability to

Lucian A. Bebchuk is the William J. Friedman and Alicia Townsend Friedman Professor of Law, Economics, and Finance, and Director of the Program on Corporate Governance, at Harvard Law School. He is also a Research Associate of the National Bureau of Economic Research. This paper develops some of the points made in an op-ed piece he published in The Wall Street Journal.

() The Berkeley Electronic Press the financial markets and protecting taxpayers. I show that the proposed legislation can be redesigned to limit greatly the cost to taxpayers while performing better in terms of restoring stability to the financial markets.

Although it is widely accepted that the current problems in the financial system result from problems in the housing market, the emergency legislation, and my analysis in this paper, focus on the current crisis of liquidity, capitalization, and confidence in the financial sector. Throughout, I accept the two stated objectives of the Treasury's plan-restoring stability to the financial sector and protecting taxpayers-and show how they can be better served by a redesigned plan.

The proposed redesign is based on four interrelated elements:

- No overpaying for troubled assets: The Treasury's authority to purchase troubled assets should be limited to doing so at fair market value.

- Addressing undercapitalization problems directly: Because the purchase of troubled assets at fair market value may leave financial firms severely under-capitalized, the Treasury's authority should be expanded to allow purchasing, again at fair market value, new securities issued by financial institutions in need of additional capital.

- Market-based discipline: to ensure that purchases are made at fair market value, the Treasury should conduct them through multibuyer competitive processes with appropriate incentives.

- Inducing infusion of private capital: to further expand the capital available to the financial sector, and to reduce the use of public funds for this purpose, financial firms should 
be required or induced to raise capital through right offerings to their existing shareholders.

Below I discuss in turn each of these four elements. In the course of my analysis, I discuss major flaws of the proposed legislation that would undermine its effectiveness and explain how the plan I put forward can address them.

\section{PURCHASING TROUBLED ASSETS}

The premise of the Treasury's plan is that

I the current crisis is due to the presence of "toxic" real-estate paper on the balance sheets. Financial firms can currently sell these "troubled assets" only at an extremely deep discount to face value if at all. The Treasury believes that the presence of these illiquid troubled assets "clogs" the financial system and is "choking off the flow of credit." Because of the substantial presence of these illiquid troubled assets on the balance sheets of financial firms, the Treasury believes, financial firms have difficulty raising capital, are subject to risks of creditor runs, and are reluctant to carry out fully their role in financing the real economy.

One reason why troubled assets cannot currently be sold at face value is probably due to the decline in the fundamental economic value of these assets due to the correction in the housing market. The Treasury believes, however, that financial firms cannot currently sell these assets even at their reduced fundamental value. In a normal, well-functioning market, with sufficient supply of interested buyers, such assets can be expected to trade at their fundamental value - the discounted present value of their "hold-to-maturity value." The Treasury believes, however, that we currently do not have such a normal, well-functioning market. Rather we have a "limits to arbitrage" situation in which money managers that would otherwise be willing to purchase financial assets at any price below their fundamental value do not have sufficient liquidity to keep prices at fundamental values. The proposed legislation seeks to provide such liquidity through the use of public funds.

Accepting the need and desirability of using public funds to provide liquidity to the market for troubled assets, the critical issue concerns the price at which the Treasury would attempt to buy these assets. The Treasury's official statements about the plan contemplate purchasing troubled assets at fair value: "The price of assets purchased will be established through market mechanism where possible, such as reverse auctions." Such an approach is appealing, of course, because purchasing assets at fair market value might enable taxpayers to get an adequate return on their investment.

While the Treasury's statements contemplate purchases at fair market value, however, the draft legislation is careful to grant the Treasury full authority to pay higher prices for troubled assets. As Aaron Edlin and others have pointed out, the draft would permit the Treasury, if it so chooses, to spend, say, $\$ 700$ billion for troubled assets with a fair value of only $\$ 200$ billion, making taxpayers poorer by half a trillion dollars.

This freedom to confer massive gifts on private parties is highly problematic. It should be constrained: the legislation should direct the Treasury to buy assets at fair market value.

Some might ask whether directing the Treasury to purchase troubled assets only at fair market value might not make the purchase program inconsequential. Would this prescription not lead the Treasury to purchase troubled assets at fire sale prices and thus not add significantly to the options available to firms. Accepting the diagnosis of our current predicament
Brought to you by | Harvard University
Authenticated

Download Date | 4/5/16 4:30 PM
Economists' Voice September, 2008 
underlying the Treasury's proposal, the answer is no. At present, the prices are viewed as substantially below fundamental value due to the drying up of liquidity and the lack of fund supply that ensures pricing at fundamental value in normal times. Thus, the fair market value that the Treasury would pay would be one that would reflect market outcomes under conditions of adequate liquidity. What mechanism will best ensure that the prices paid for troubled assets purchased for taxpayers would indeed reflect such outcomes is a question I will take up later on.

\section{DEALING DIRECTLY WITH UNDERCAPITALIZATION} PROBLEMS

$\mathrm{R} y$ itself, imposing the fair market value constraint on purchases of troubled assets might leave us with stability concerns that the Treasury sought to address by retaining the power to overpay. Because the depressed housing market reduced the fundamental value of troubled assets, some financial firms may well remain seriously under-capitalized even if they could sell troubled assets at fair value. The Treasury wants the power to overpay for troubled assets to be able to improve the capital position of these firms to restore stability and prevent creditor runs.

Let us suppose for the time being, as the Treasury's plan does, that infusion of additional capital to financial firms must at this point come, at least to a substantial degree, from the government. Even so, such infusion of capital should not be done by giving gifts to the shareholders and bondholders of financial firms through over-paying for their assets. Rather, the provision of such additional capital should be done directly, aboveboard, and for consideration.

While the Treasury's draft legislation gives it large and unusual powers, some of which need to be scaled back, there is one power that the Treasury was not given but should be. The draft legislation allows the Treasury to purchase only pre-existing assets. This limitation shoots taxpayers in the foot, preventing the government from getting newly issued securities from firms receiving capital infusions from it. This limitation should be revised to allow the Treasury to purchase-again only at fair market value-new securities in financial firms when doing so is necessary for stabilizing financial markets.
Authorizing the provision of capital in return for newly issued securities is far superior to authorizing, as the current draft does, the provision of capital through overpaying for troubled assets. To begin, taxpayers would be better protected; they would get adequate consideration for the capital they are providing rather than nothing at all, as under the Treasury's plan which provides capital through subsidized purchases of troubled assets.

Furthermore, the direct approach would do a better job in providing capital where it is most useful. If the proposed legislation were implemented, capital would be inefficiently channeled, as the amount of troubled assets sold by firms would not necessarily be related to the amount of capital that they need and should get from the government.

Before moving on, I should comment on another approach that some lawmakers (such as Senator Christopher Dodd) and commentators (such as Paul Krugman) have raised: directing the government to insist on getting some newly issued securities — shares or warrants-in financial firms from which the government would purchase troubled assets. These proposals have been motivated by similar concerns to the one
Brought to you by | Harvard University
Authenticated

Download Date | 4/5/16 4:30 PM.
$-3-$
Economists' Voice September, 2008 
I have - that the Treasury's plan contemplates subsidizing some firm through overpaying for their troubled assets. To the extent that such overpaying will happen to shore up the firms' capital positions, these observers ask, why should the government not get at least some equity tickets to compensate it for the subsidized purchase of troubled assets?

While the motivation for these suggestions is understandable, and while they go in the direction I advocate-preventing the government from subsidizing firms from which troubled assets are purchased-they still unnecessarily tie together purchases of troubled assets and provision of new capital. Such tie-in does not reduce the government's need for information or make matters otherwise simpler: the government would still need to assess how much it is overpaying for the purchased troubled assets and what new equity tickets would provide adequate consideration for the amount overpaid, which would require the government to determine both the fair market value of the troubled assets and the fair market value of new equity securities issued to it.

In such a case, there would be no reason not to proceed in a manner reflecting explicitly and aboveboard the transactions taking place - that is, specify separately the price paid for the troubled assets (in a transaction aimed at paying fair market value for them) and the price paid for the new equity securities (in a transaction aimed at paying fair market value for them). Moreover, tying equity participations to purchases of troubled assets is problematic because of the already mentioned lack of correlation between the need for governmental purchases of troubled assets and the desirability of governmental infusion of capital. Some financial firms would like to sell a substantial amount of troubled assets to the government but do not need a governmental infusion of capital; and, conversely, some financial firms would need a capital infusion but would not wish to make significant use of the government's willingness to purchase troubled assets.

Before concluding the discussion of capital provision for adequate consideration in newly issued securities, it should be stressed that this is possible only for financial firms that are undercapitalized but still solvent. If a firm is insolvent and its shares thus do not have a positive fundamental value, any number of new equity securities may be insufficient to provide the government with adequate consideration. In such a case, the process of infusing new capital for adequate consideration-whose implementation I describe below-would not result in an infusion of new capital. Even in a highly liquid and well-functioning market, a firm that is insolvent would not be able to get capital by selling additional equity participations

Thus, even with (i) a mechanism for using public funds to provide liquidity to the market for troubled assets and enable firms to sell such assets at fair value, and (ii) a mechanism for using public funds to provide liquidity to the market for new capital for financial firms to enable such firms to sell new equity shares at fair market value, the government might well face a subset of financial firms that would be insolvent. For those firms that are either federally insured (banks) or whose bankruptcy would have sufficiently large negative system-wide effects, the government may decide to have a "bailout." Such a bailout, however, should involve wiping out shareholders' stakes, with the government effectively getting the full value of equity in return for its support. For those firms that are not federally

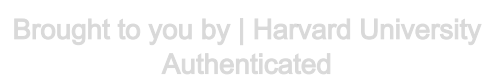

Download Date | 4/5/16 4:30 PM.
Economists' Voice September, 2008 
insured and whose bankruptcy would not be judged to have sufficiently large negative system-wide effects, the government should let the insolvency proceed through standard processes (as it has decided to do in the case of Lehman Brothers).

Because the decline in the fundamental value of troubled assets may have rendered some financial firms truly insolvent, some bailouts and/or bankruptcies of financial firms may be unavoidable even under the proposed plan for using public funds to purchase troubled assets and new equity securities at fair value. However, that would hardly mean that the availability of mechanisms (i) and (ii) above-using public funds to provide liquidity in the markets for troubled assets and new capital for financial firms-would not be valuable. These mechanisms would ensure that bailouts and bankruptcies would be limited to that subset of firms-which would hopefully turn out not to be substantial in scope-that would be insolvent even in the absence of liquidity problems and market disruptions, namely, even if they could sell troubled assets and new equity participations at prices reflecting fundamental values.

\section{MARKET-BASED MECHANISMS FOR PURCHASING}

\section{ASSETS AT FAIR MARKET VALUE}

The plan I am putting forward would auI thorize the governments to use public funds both to purchase troubled assets, as the Treasury plan suggests, and to purchase newly issued securities by financial firms in need of additional capital. Both types of purchases should be at fair market value. The devil, however, is in the details. How would the government know whether it is purchasing assets at fair market value and avoiding over-paying for assets at taxpayers' expense?

The proposed legislation allows the Treasury to conduct purchases through in-house operations, outside delegation, or any other method it chooses. It would be best, however, to direct the Treasury to operate through agents with strong market incentives.

Suppose that the economy has illiquid mortgage assets with a face value of $\$ 1,000$ billion, and that the Treasury believes that the introduction of buyers armed with $\$ 100$ billion could bring the necessary liquidity to this market. The Treasury could divide the $\$ 100$ billion into, say, 20 funds of $\$ 5$ billion and place each fund under a manager verified to have no conflicting interests. Each manager could be promised a fee equal to, say, $5 \%$ of the profit its fund generates-that is, the excess of the fund's final value down the road over the $\$ 5$ billion of initial investment. The competition among these 20 funds would prevent the price paid for the mortgage assets from falling below fair value, and the fund managers' profit incentives would prevent the price from exceeding fair value.

The above example is intended to illustrate the point, of course, rather than to suggest particular details for the fee structure of the funds' managers. It would be necessary to determine the percentage of profits granted to managers and the threshold above which this percentage would be applied. One could consider taking the competitive idea one additional step: after a pool of candidates that pass threshold conditions in terms of expertise and lack of conflicting interests is selected, the selection could be based on bidding process in which candidates would bid the profit percentage for which they would be willing to manage a fund.

Given that the decentralized system I am describing is far from straightforward, let me explain why it might nonetheless be preferable 
to having the government conduct purchases of a given class of assets through a single buyer, possibly located in house in the Treasury. Certainly, a situation in which a Treasury in-house official bargained one-on-one with a financial firm over the value of an asset would raise serious concerns. The Treasury's statement sought to allay these concerns by raising the possibility of using market mechanisms such as auctions or reverse auctions.

Suppose that the Treasury seeks to purchase some units within a certain class of assets—say, trench C in mortgage pool M. Under one possible procedure described by Chairman Bernanke in Congressional testimony, the Treasury could name a price it is willing to pay per unit, based on its estimate of the hold-to-maturity value of these units, and financial firms would then decide to sell. But estimating accurately the hold-to-maturity value requires making estimates of the incidence of mortgage re-payment years down the road, and it would be rather difficult for a Treasury official-or for those reviewing the official's decisions-to know whether the estimate made by the official is close to or far from accuracy. Indeed, it would be difficult to know this even in retrospect; if hold-to-maturity returns fall below the price paid, this might be due to negative realization of uncertainty rather than to the use of an estimate that was too low when made.

Moreover, the Treasury official would face private actors with powerful incentives to maximize their interests. Thus, even if Treasury officials are as likely to err in one direction as in the other in making their estimates, the result would be systematic overpaying for assets. For sellers would be more likely to accept the price named by Treasury for units of trench $C$ of pool $\mathrm{M}$ when the price is set too high and less likely to do so when the price is set too low.

An alternative procedure that a centralized one-buyer process could use would specify not the price that the Treasury is willing to pay for units in the class of assets but the number of units it is seeking to acquire-say, $50 \%$ of the units. The Treasury would then invite owners of units to submit offers as to the price at which they are willing to sell such assets, and it would purchase units at whatever level is sufficient to induce sale offers for the $50 \%$ of the units. In theory, this could work when ownership of units in this class of assets is dispersed among owners that cannot effectively coordinate the prices they would demand. However, in situations in which assets are owned by a concentrated group or by repeat players that can implicitly coordinate strategies, such auctions may produce inflated prices.

\section{MANDATING RIGHTS OFFERINGS}

y discussion thus far assumed, following Ithe assumption underlying the Treasury's plan, that, because capital markets "froze," new capital infusions to financial firms need, at least to a substantial degree, to come from the government. However, financial firms that are undercapitalized but clearly solvent, as many financial firms seem to be, should be able to raise significant additional capital from private sources. It should be emphasized that the government has thus far not exhausted its options in terms of inducing financial firms to raise additional capital from private sources.

Following the Bear Stearns collapse in March, the government urged and encouraged some financial firms to raise additional capital. However, the government has not thus far required financial firms to go out and raise additional capital, and it should do so. As was suggested by Raghuram Rajan in a recent op-ed

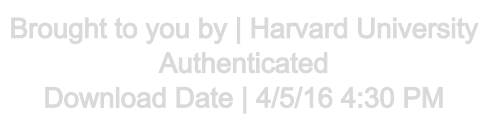


piece in the Financial Times, the government could and should require financial firms that have substantial but sub-optimal capitalization to raise capital through rights offerings to existing shareholders. While such rights offerings would not be effective for firms in relatively fragile situations, they could bring significant additional capital to firms that are clearly solvent; this would substantially increase the aggregate capital available to the financial sector and, in turn, expand the pool of credit available to Main Street. There can be little doubt that if, say, Bank of America were required to make a rights offering at a price significantly below its current market price, the offering would be fully subscribed, would bring in significant additional capital, and hence would expand the capacity of this bank to provide financing to the real economy.

Because the proposed legislation is partly motivated by a concern that the financial sector's undercapitalization might undermine its ability to finance Main Street, mandating such rights offerings would contribute substantially to addressing this concern. Furthermore, it would do so at no cost to taxpayers. Thus, mandating rights offerings for an appropriate subset of the country's financial firms should be a useful supplement to (and partial substitute for) the use of public funds for these purposes.

The case for mandating rights offerings might be questioned on grounds that firms can, of course, choose on their own to raise new equity capital through rights offerings or otherwise. A mandate would necessarily be harmful in situations in which a firm on its own would choose not to do a rights offering, so the argument goes, and would be unnecessary in situations in which firms would choose to do so on their own. But this critique should not be accepted for two reasons.

To begin, as pointed out by Rajan, a "lemons" problem-in particular, fear of negative informational inferences that the market may draw from a decision to make a rights offering-might discourage a firm from doing so even if it needs capital. In contrast, when a rights offering is mandated by the government for a substantial set of firms, the market will not draw a negative inference about the managers' private information from the existence of a rights offering. Furthermore, the premise of the Treasury's plan is that the existence of adequate capitalization in given financial firms has substantial positive spill-over effects on other firms in the economy. The existence of such effects might well make it desirable in the current circumstances to expand the capital available to financial firms even if financial firms' existing shareholders would privately prefer not to do so in order to avoid diluting their earnings.

\section{CONCLUSION}

Recause the Treasury's plan would infuse capBital through overpaying for troubled assets, it would impose massive costs on taxpayers and might not channel needed capital to its most valuable uses. The proposal put forward in this paper would do a far better job both in terms of protecting taxpayers and in terms of restoring financial stability.

Because I focus in this paper on the financial sector problems that the Treasury proposal seeks to address, I have abstracted from the problem of the housing market. It is generally recognized that the financial sector's problems are in part due to the "correction" in the housing market. Nonetheless, the assumption underlying the Treasury's plan is that government intervention should focus

Economists' Voice September, 2008
$-7-$ 
on the financial sector. The Treasury (now) recognizes that the problems of the financial markets should not be left to the market to sort out but rather require government intervention. However, once this intervention brings stability and liquidity to financial firms, the Treasury believes, the problems of the housing market can still be left for market forces to sort out. Unfortunately, however, the housing market is not a Coasian setting in which such adjustments can occur without much cost. Thus, additional government intervention in connection with the housing market may be warranted alongside the intervention in the financial markets that has been the focus of this short paper. Whether and what intervention would be warranted is a question that is beyond the scope of the present paper, however, and I plan to consider it in separate work.

Letters commenting on this piece or others may be submitted at submit.cgi? context=ev.

\section{REFERENCES AND FURTHER READING}

Bebchuk, Lucian (2008) "How to Pay Less for Distressed Financial Assets," The Wall Street Journal, September 26. http://wsj.

net/article/SB122238704668077137.html.

Edlin, Aaron (2008) "Questioning the Treasury's $\$ 700$ Billion Blank Check: An Open Letter to Secretary Paulson," The Economists' Voice, 5(5): Art. 4. vol5/iss5/art4

Rajan, Raghuram (2008) "Desperate Times Need the Right Measures," FT.com, September 19.

Treasury Department (2008) Proposed legislation. viewcontent.cgi?

context $=$ ev\&article $=1408 \&$ file

name $=0 \&$ type $=$ additional. 